\title{
COMPORTAMIENTO DE CUATRO CULTIVARES DE CUCURBITA MAXIMA CV. ZAPALLITO FRENTE AL PARASITISMO DEL NEMATODO DE LAS AGALLAS MELOIDOGYNE INCOGNITA
}

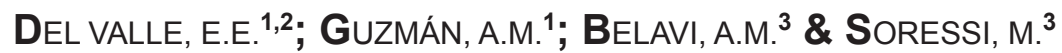

\begin{abstract}
RESUMEN
El nematodo de las agallas, Meloidogyne incognita, es causante de pérdidas productivas en los principales cultivos hortícolas que se realizan en el albardón costero santafesino. El objetivo de la investigación fue determinar la reacción de cuatro cultivares comerciales de zapallito redondo de tronco (Cucurbita maxima cv. zapallito) frente al parasitismo de M. incognita. Las experiencias se condujeron en macetas bajo invernadero y se evaluaron los cultivares Nacional, Premier, Sais superselección y Máximo. Los tratamientos consistieron en inocular plantas de cada cultivar con 100 juveniles de segundo estadio de M. incognita y de sus correspondientes testigos no inoculados. A los 45 días de la inoculación se determinó el número de agallas, Índice de Agallas, número de masas de huevos, Índice de Masas de Huevos, número de huevos y el factor e reproducción. Los cuatro cultivares estudiados demostraron ser susceptibles a M. incognita.
\end{abstract}

Palabras claves: Nematodo de las agallas, zapallito redondo de tronco, Meloidogyne incognita.

\section{SUMMARY}

The root-knot nematode, Meloidogyne incognita, causes yield losses in many horticultural crops in the coastal área of Santa Fe province. The aim of this research was to determine the reaction of four commercial cultivars of summer squash (Cucurbita maxima cv. zapallito) when parasitized by M. incognita. The experiments were conducted in pots under greenhouse conditions and Nacional, Premier, Sais superselection and Máximo cultivars were evaluated. The treatments consisted of plants of each cultivar inoculated with 100 second-stage juveniles of $M$. incognita and its corresponding control. 45 days after inoculation the number of galls, Gall Index, number of egg masses, Eggs Mass Index, number of eggs and reproduction factor were determined. The four cultivars studied showed susceptibility to M. incognita.

Keywords: Root-knot nematodes, summer squash, Meloidogyne incognita.

${ }^{1}$ Facultad de Ciencias Agrarias, Universidad Nacional del Litoral, Kreder 2805. (3080) Esperanza, provincia de Santa Fe, E-mail: edelvalle@fca.unl.edu.ar

${ }^{2}$ Consejo Nacional de Investigaciones Científicas y Técnicas, Argentina.

${ }^{3}$ Instituto Nacional de Tecnología Agropecuaria, Ruta Prov. 2 Nro. 2400. (3014) Monte Vera, Santa Fe.

Manuscrito recibido el 28 de noviembre de 2013 y aceptado para su publicación el 5 de marzo de 2014. 